\title{
Pumping and injection well spacing of Water Heat Pump on the influence of the groundwater flow field and temperature field analysis
}

\author{
Yueren Wang, Wen Lou \& Chenfei Bi *
}

School of Municipal and Environmental Engineering, Shenyang JianZhu University, Shenyang, Liaoning, China

KEYWORD: Inter-well distance, Groundwater level, Temperature and thermal transfixion

\begin{abstract}
As the distance between production well and injection well, distribution of wells and operation model of water resource heat-pump system play a significant impact on system efficiency. The paper makes a research on changes in water flow field and temperature field around production and injection wells. Taking a Shenyang residential area; a water-source heat-pump system as example, the paper does the research on the basis of coupling model and analyzes the variation characteristics of the research objects with the help of Flow Heat software when the inter-well distance are $20 \mathrm{~m} 、 30 \mathrm{~m} 、 40 \mathrm{~m} 、 50 \mathrm{~m} 、 60 \mathrm{~m} 、 70 \mathrm{~min}$ the winter. The result shows that a longer distance will take longer time for thermal transfixion which in a slighter degree. Therefore, the conclusion is the optimum distance between water-source heat-pump production well and injection well should be $30 \mathrm{~m}$.
\end{abstract}

\section{INTRODUCTION}

Now both energy consumption and serious environmental damage, The underground water source heat pump technology as a way of sustainable development and utilization of geothermal energy has been widely promotion and application.Underground water source heat pump system is mainly based on shallow groundwater as the cold and heat source, can be provided to indoor refrigeration and heat.Due to the effect of common of the flow field and temperature field,make injection cold (or hot) water in the aquifer movement,and well spacing, heat convection, operation mode and other factors, Which reduces the efficiency[1].Among them, the size of the hole spacing directly affects the degree of thermal transfixion underground water source heat pump system.In addition, because residential area usually adopt winter heating in north China, the other three seasons at operation mode, so the groundwater temperature and the influence of the change of the flow field is more obvious. To this end, we in Shenyang area as an example of a residential district,using the Flow Heat1.0 software, analysis under different pumping well spacing, pumping Wells surrounding the change of the groundwater flow field and temperature field,prevent the occurrence of heat transfixion phenomenon, provide theoretical basis for improving the system efficiency.

\section{PROFILE OF THE STUDY AREA}

Shenyang city mainly for sand and gravel strata, generally the burial depth of the underground water level at 6.0-9.0 m,layer thickness is bigger, average $18.0-40.0 \mathrm{~m}$, the permeability coefficient is about $100 \mathrm{~m} / \mathrm{d}$.Shenyang groundwater depth basic and consistent changes in terrain slope, showing east to the west of the underlying trend.Shenyang in most areas to meet the basic requirements of water and recharge groundwater source heat pump projects, while the northeastern city of permeability coefficient is small, it is difficult to meet the water requirements of groundwater source heat pump[2].So the study area as Shenyang Tie Xi Area residential building area of 50,000 square meters, geomorphology mainly Hun He new alluvial fan, without considering the impact of natural groundwater hydraulic gradient.Heating time is November 1 to April 1, when the length of 150 days for the $24 \mathrm{~h}$ continuous operation during system operation. 


\section{MODELING}

\subsection{Mathematical Model}

HST3D to Darcy's law and mass conservation law as the basis, the coupled flow and solute transport equation equation saturated groundwater discrete finite difference method in order to solve the pressure, temperature and solute concentration.The solving of the flow and heat transfer equation is:

HST3D saturated aquifer groundwater flow equations [3]:

$$
\frac{\partial(n \rho)}{\partial t}=\Delta \frac{\rho k}{\mu}(\Delta P+\rho g)+\rho_{s} q
$$

Where $\mathrm{n}$ is the effective porosity of the medium aquifer; $\mathrm{P}$ is the fluid pressure $/ \mathrm{Pa} ;{ }^{\rho}$ is the fluid density / $\left(\mathrm{kg} / \mathrm{m}^{3}\right) ;{ }^{\rho}$ is the fluid source term density / $\left(\mathrm{kg} / \mathrm{m}^{3}\right) ; \mathrm{K}$ is the permeability tensor porous medium $/ \mathrm{m}^{2} .{ }^{\mu}$ Is the driving force viscosity coefficient $/(\mathrm{kg} /(\mathrm{m} \cdot \mathrm{s})) ; \mathrm{G}$ is the gravitational acceleration / $\left(\mathrm{m} / \mathrm{s}^{2}\right)$; $\mathrm{Q}$ is the source and sink terms intensity / $\left(\mathrm{m}^{3} /\left(\mathrm{m}^{3} \cdot \mathrm{s}\right)\right)$; T is the time / $\mathrm{s}[4]$.

HST3D saturated aquifer Heat transfer equations[3]:

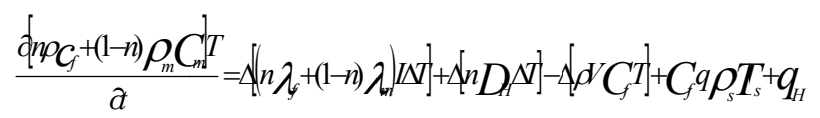

Where $\mathrm{T}$ is the aquifer temperature $/{ }^{\circ} \mathrm{C} ; T_{s}$ is the source point temperature $/{ }^{\circ} \mathrm{C} ; \rho_{m}$ is medium density solid / $\left(\mathrm{kg} / \mathrm{m}^{3}\right) ;{ }^{C_{f}}$ and ${ }^{C_{m}}$ are the fluid phase and the solid phase heat $/\left(\mathrm{J} /\left(\mathrm{kg} \cdot{ }^{\circ} \mathrm{C}\right)\right) ;{ }^{\lambda_{f}}$ and $\lambda_{m}$ are the Fluid phase and solid phase thermal conductivity / ( W / $\left.\left(\mathrm{m} \cdot{ }^{\circ} \mathrm{C}\right)\right) ; \mathrm{I}$ is a three-dimensional unit vector; $D_{H}$ is the thermal mechanical dispersion tensor $/\left(\mathrm{W} /\left(\mathrm{m} \cdot{ }^{\circ} \mathrm{C}\right)\right) ; q_{H}$ is heat intensity / $\left(\mathrm{W} / \mathrm{m}^{3}\right) ; \mathrm{V}$ is the Darcy velocity vector / $(\mathrm{m} / \mathrm{s})$ [4].

\subsection{Physical Model}

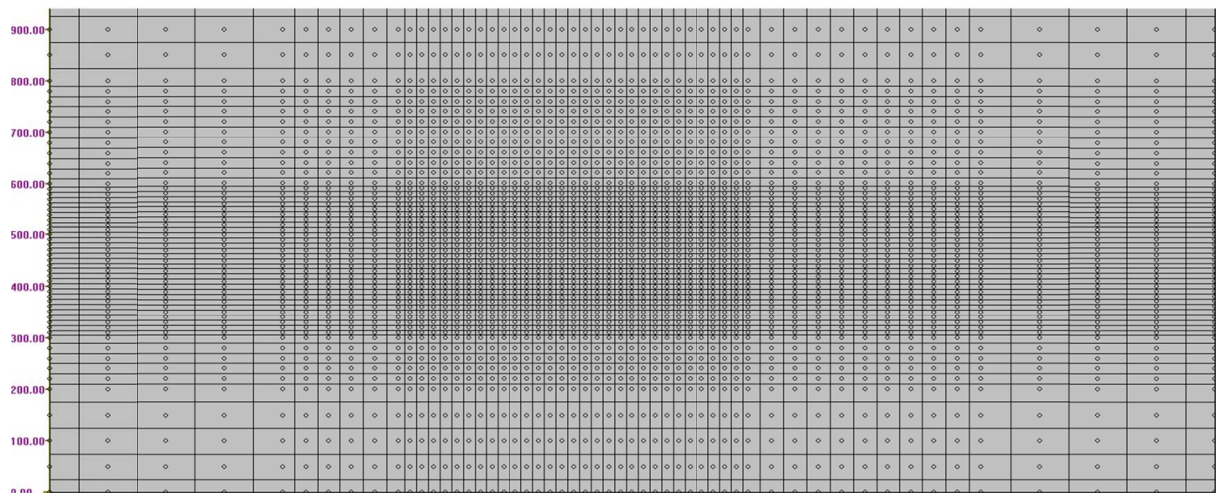

Figure 3.1 Flat area meshing

Meshing: In order to improve the accuracy and speed of calculation, the plane of the region using non-equidistant mesh,close mesh infill wells group area, outside the grid gradually widened,centralized water and recharge area within $350 \times 350 \mathrm{~m}^{2}$ range,grid spacing is $10 \mathrm{~m}$, maximum spacing of periphery is $50 \mathrm{~m}$.

Boundary conditions: four sides of the study area is constant head boundary layer, top and bottom is thermal and impermeable boundary layer.

Aquifer parameters: According to the relevant hydrogeological materials, sand aquifer parameters in Table 3.1 [5] 
Table 3.1 Coarse sand aquifer parameters

\begin{tabular}{lllllll}
\hline Categor & $\begin{array}{l}\text { Permea } \\
\text { bility } \\
(\mathrm{m} / \mathrm{d})\end{array}$ & $\begin{array}{l}\text { Poros } \\
\text { ity }\end{array}$ & $\begin{array}{l}\text { Longitu } \\
\text { dinal } \\
\text { dispersi } \\
\text { ty } \\
(\mathrm{m})\end{array}$ & $\begin{array}{l}\text { Trans } \\
\text { verse } \\
\text { disper } \\
\text { sity } \\
(\mathrm{m})\end{array}$ & $\begin{array}{l}\text { Specific } \\
\text { heat } \\
\text { capacity } \\
\left(\mathrm{MJ} / \mathrm{m}^{3}\right)\end{array}$ & $\begin{array}{l}\text { Thermal } \\
\text { conductivit } \\
\mathrm{W} /\left(\mathrm{m} \cdot{ }^{\circ} \mathrm{C}\right)\end{array}$ \\
\hline $\begin{array}{l}\text { Coarsesa } \\
\text { nd }\end{array}$ & 0.343 & 0.38 & 2.4 & 0.6 & 2.2 & 2.0 \\
\hline
\end{tabular}

\section{THE LAYOUT SCHEME OF WELL GROUP}

According to the regional hydrogeological conditions and the relevant technical specifications to determine the number of pumping irrigation wells, the area of construction is $50,000 \mathrm{~m}^{2}$, energy-efficient heat load indicators is $35 \mathrm{w} / \mathrm{m}^{2}$, design heat load is $1750 \mathrm{kw}$, design water is $250 \mathrm{~m}^{3} / \mathrm{h}$. Reference the test data and geological conditions of the study area to determine out of water of the single well in this study is $125 \mathrm{~m}^{3} / \mathrm{h}$ [2]; requiring two pumping wells, a spare, using 1: 2 recharge,recharge amount of a single well is $62.5 \mathrm{~m}^{3} / \mathrm{h}$, if $100 \%$ recharge, we need four recharge wells,considering the actual injection of running water infiltration rate is low and the water pump maintenance needs, equipped with 1 spare injection wells.Due to ignoring the influence of the hydraulic gradient, so the initial water head is 0 , aquifer initial temperature is $13{ }^{\circ} \mathrm{C}$, the injection temperature of winter is $7{ }^{\circ} \mathrm{C}$, well depth is $60 \mathrm{~m}$. Therefore, the number of exploration wells identified as "the two pumping wells and four recharge wells"(Spare a pumping wells and a recharge well).

\section{PUMPING WELL AND INJECTION WELL SPACING EFFECT ON THE UNDERGROUND FLOW FIELD ANALYSIS}

The six wells of this study layout for double linear pumping and recharge mode,pumping well spacing respectively 20,30, 30, 50, 60, $70 \mathrm{~m}$ five kinds of situations. (In the middle of the two is pumping Wells,North and south sides of two injection Wells,A total of two pumping Wells and four injection Wells).

North

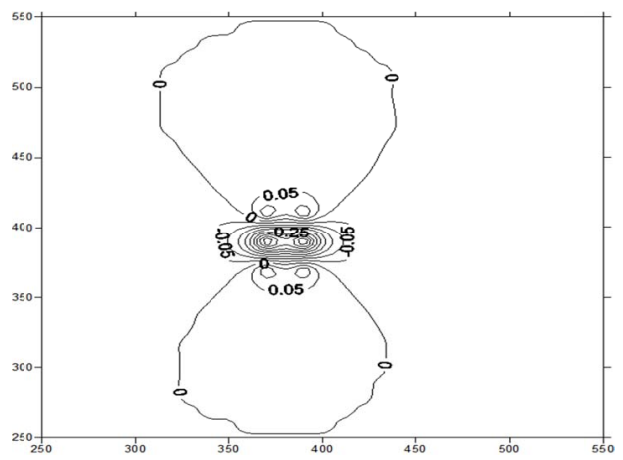

Spacing of $20 \mathrm{~m}$ level contour map

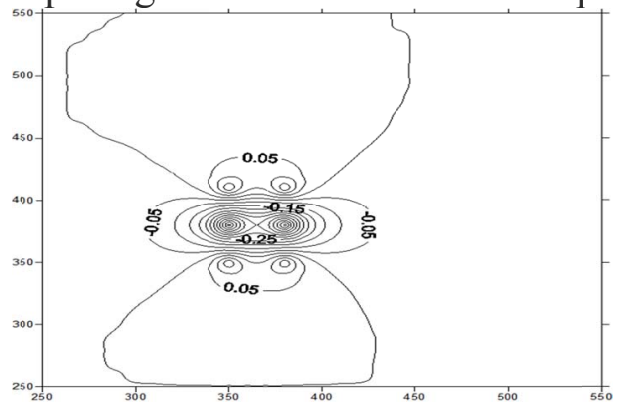

Spacing of $30 \mathrm{~m}$ level contour map 


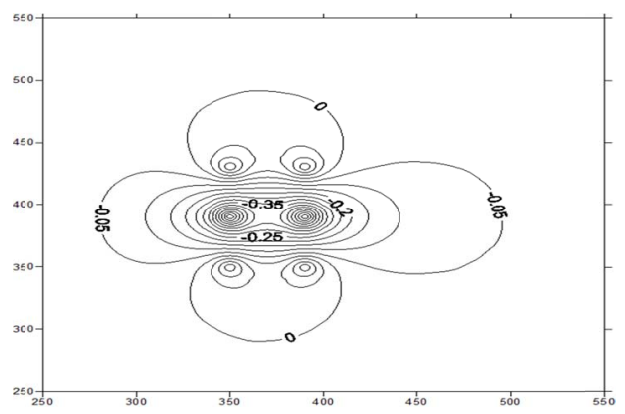

Spacing of $40 \mathrm{~m}$ level contour map

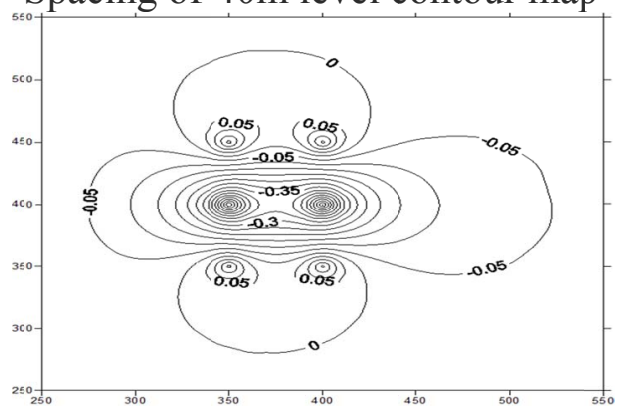

Spacing of 50m level contour map

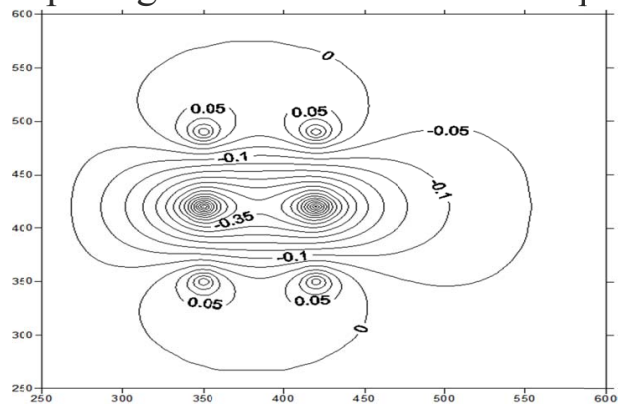

Spacing of $70 \mathrm{~m}$ level contour map

The figure above you can see the following:

1) Can be seen from the six picture, water level of the pumping wells and injection wells contour level symmetrical distribution,the reason is the research scope is small,aquifer lithology are coarse sand, and the groundwater flows from east to west.

2) With the increase of well spacing, the water level of pumping Wells is falling, recharge well water level rising gradually.Water level of the pumping Wells and injection Wells contour gradually became independent of the ellipse, that means with the increase of spacing groundwater flow velocity influence on water level gradually smaller.

3 ) With the increase of pumping well spacing, the level of pumping Wells and injection Wells influence scope is gradually increased.

4) Pumping well spacing is $20 \mathrm{~m}$,run the end of the pumping well water level dropped to 1.1309 $\mathrm{m}$ and $1.1311 \mathrm{~m}$,Injection Wells rose to $0.3724 \mathrm{~m}$. Pumping well spacing is $70 \mathrm{~m}$, run the end of the pumping well water level dropped to $1.1309 \mathrm{~m}$ and $1.1311 \mathrm{~m}$,injection Wells rose to $0.4471 \mathrm{~m}$. 


\section{PUMPING WELL AND INJECTION WELL SPACING EFFECT ON THE}

UNDERGROUND TEMPERATURE FIELD ANALYSIS

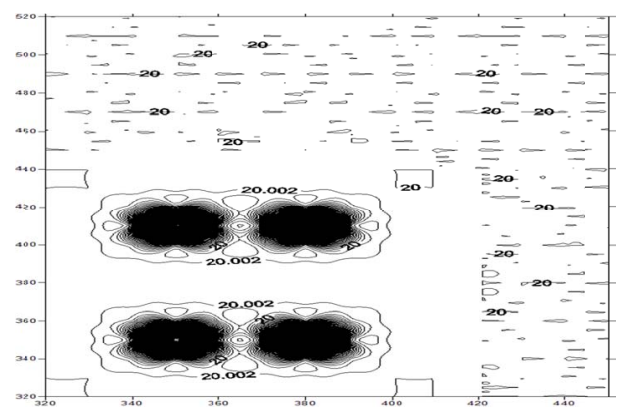

Spacing of 20mtemperature contour map

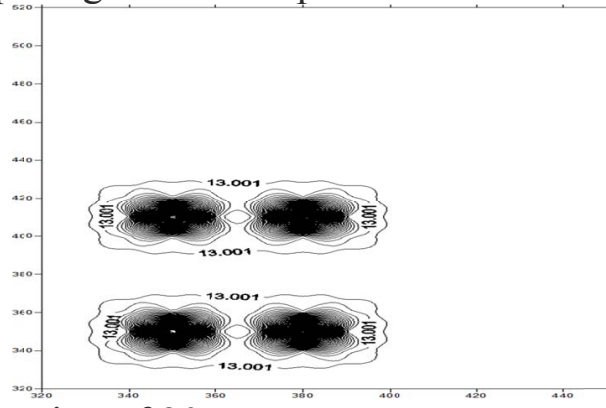

Spacing of 30mtemperature contour map

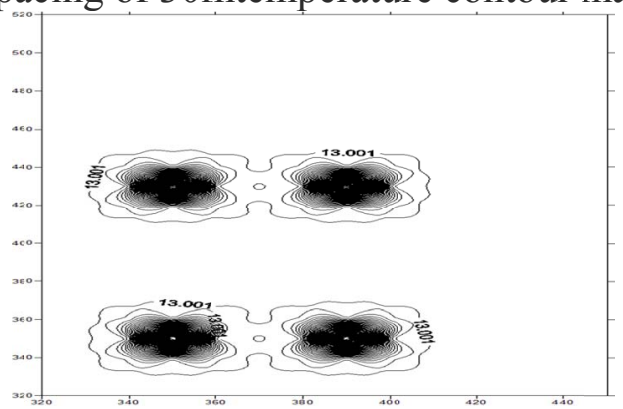

Spacing of 40mtemperature contour map

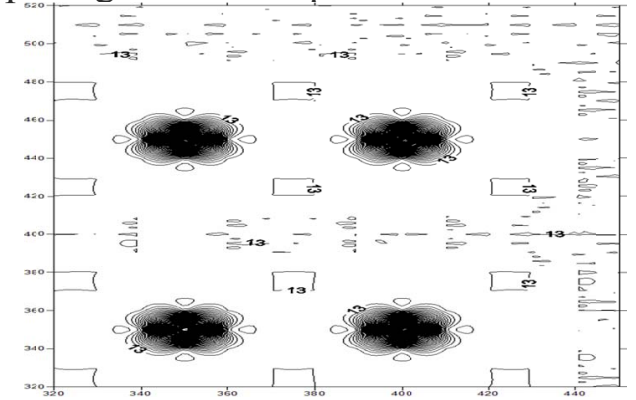

Spacing of 50mtemperature contour map

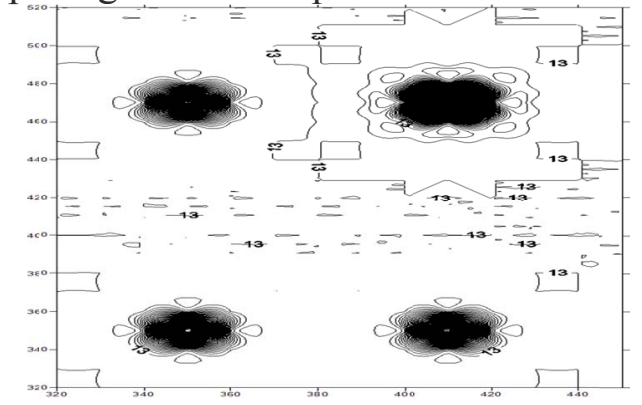

Spacing of 60mtemperature contour map 


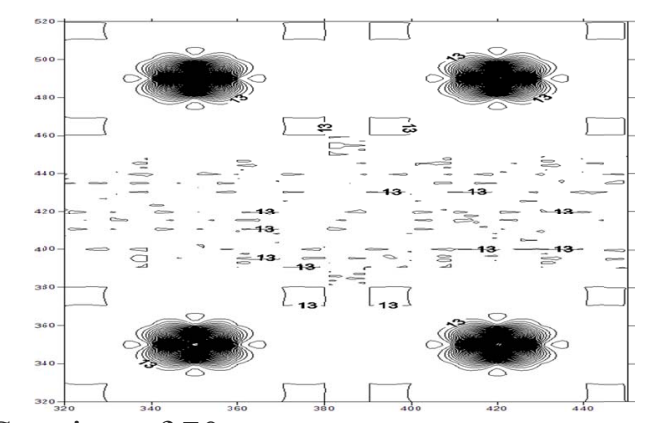

Spacing of 70mtemperature contour map

As can be seen from Figure above the following:

1)Six images from a pumping wells and two recharge wells between north and south can be seen as well from the impact of an increase in pumping wells by the north and south sides of recharge wells cold fronts decreases heat penetration phenomenon more and more obvious.

2)With the irrigation wells pumping from the increase, the cold fronts two recharge wells independently of each other.

3)Pumping well spacing is $20 \mathrm{~m}$,run the end of the pumping well temperature dropped to $5.209^{\circ} \mathrm{C}$ and $5.213^{\circ} \mathrm{C}$,Pumping well spacing is $70 \mathrm{~m}$, run the end of the pumping well temperature dropped to $1.485^{\circ} \mathrm{C}$ and $1.410^{\circ} \mathrm{C}$.

\section{OPTIMIZATION OF PUMPING IRRIGATION WELL SPACING}

Table 7.1 for different irrigation wells pumping from mode to simulate the temperature changes of pumping wells and pumping wells and recharge wells the water level changes.It can be seen at the end of the heating operation, water pumping wells and recharge wells draw down is less than $1.5 \mathrm{~m}$, will not affect the normal amount of pumping and recharge, so you can ignore the impact of seepage field on GWHP well group arrangement, only consider pumping wells temperature change on well spacing.With pumping irrigation wells pumping from wells to increase the temperature difference decreases, considering the actual project area and economy as well as pumping wells and recharge wells temperature changes, we believe that the use of irrigation wells pumping distance of at least $30 \mathrm{~m}$.

Table 7.1 Double line pumping mode temperature change of different well spacing

\begin{tabular}{|c|c|c|c|c|c|c|c|c|c|c|}
\hline \multicolumn{2}{|c|}{$\begin{array}{l}\text { Flow } \\
\left(\mathrm{m}^{3} / \mathrm{h}\right)\end{array}$} & \multirow{2}{*}{$\begin{array}{l}\text { Well } \\
\text { spaci } \\
\text { ng } \\
(\mathrm{m})\end{array}$} & \multirow{2}{*}{$\begin{array}{l}\text { Aquif } \\
\text { er } \\
\text { initial } \\
\text { tempe } \\
\text { rature } \\
\left({ }^{\circ} \mathrm{C}\right)\end{array}$} & \multicolumn{2}{|c|}{$\begin{array}{l}\text { Pumping well } \\
\text { temperature when } \\
\text { running late }\left({ }^{\circ} \mathrm{C}\right)\end{array}$} & \multicolumn{2}{|c|}{$\begin{array}{l}\text { Temperature } \\
\text { difference value } \\
\left({ }^{\circ} \mathrm{C}\right)\end{array}$} & \multicolumn{2}{|c|}{$\begin{array}{l}\text { The absolute } \\
\text { value of pumping } \\
\text { draw down (m) }\end{array}$} & \multirow{2}{*}{$\begin{array}{l}\text { The } \\
\text { value of } \\
\text { injection } \\
\text { Wells up } \\
\text { (m) }\end{array}$} \\
\hline $\begin{array}{l}\text { Pumpi } \\
\text { ng well }\end{array}$ & $\begin{array}{l}\text { Recha } \\
\text { rge } \\
\text { well }\end{array}$ & & & $\begin{array}{l}\text { Pumpi } \\
\text { ng } \\
\text { well1 }\end{array}$ & $\begin{array}{l}\text { Pumpin } \\
\mathrm{g} \text { well2 }\end{array}$ & $\begin{array}{l}\text { Pumpin } \\
\text { g well1 }\end{array}$ & $\begin{array}{l}\text { Pumpi } \\
\text { ng } \\
\text { well2 }\end{array}$ & $\begin{array}{l}\text { Pumpi } \\
\text { ng } \\
\text { well1 }\end{array}$ & $\begin{array}{l}\text { Pumpi } \\
\text { ng } \\
\text { well2 }\end{array}$ & \\
\hline \multirow{6}{*}{125} & \multirow{6}{*}{62.5} & 20 & 13 & 7.791 & 7.787 & 5.209 & 5.213 & 1.1309 & 1.1311 & 0.3724 \\
\hline & & 30 & 13 & 8.200 & 8.187 & 4.800 & 4.813 & 1.2086 & 1.2097 & 0.3825 \\
\hline & & 40 & 13 & 8.828 & 8.802 & 4.172 & 4.198 & 1.3167 & 1.3190 & 0.3886 \\
\hline & & 50 & 13 & 9.710 & 9.684 & 3.290 & 3.316 & 1.3532 & 1.3571 & 0.4120 \\
\hline & & 60 & 13 & 10.645 & 10.621 & 2.357 & 2.380 & 1.3246 & 1.3305 & 0.4341 \\
\hline & & 70 & 13 & 11.515 & 11.490 & 1.485 & 1.410 & 1.4028 & 1.4108 & 0.4471 \\
\hline
\end{tabular}

\section{CONCLUSION}

This study used the FLOW HEAT1.0 software,Established HST3D-cug model.Analog dual linear pumping irrigation pattern, well spacing, respectively $20 \mathrm{~m}, 30 \mathrm{~m}, 40 \mathrm{~m}, 50 \mathrm{~m}, 60 \mathrm{~m}, 70 \mathrm{~m}$ impact on 
irrigation pumping well group arrangement,final conclusions are as follows:

1) In practical engineering, the main factors influencing the groundwater thermal transport is groundwater convection and heat conduction. To slow the occurrence of heat through the pumping wells should try to increase the distance between the irrigation wells.

2) Receiving area limits, in practical engineering in the study of regional hydrogeology and construction and utilization condition, optimization study of pumping well spacing is $30 \mathrm{~m}$.

\section{REFERENCES}

[1] $\mathrm{Yu}$ Linhong, Study on the Ground Water Heat Pump System experimental and well group arrangement optimization, Chang 'an university 2012, 6

[2] Wang Xinbei,Xi Fengming,Di Yong,Ground source heat pump technology, energy conservation and emissions reduction benefits assessment and management model optimization research,Mechanical industry press,2013, 2

[3] Bei Er,I Porous media fluid dynamics [M].Li Jingsheng,Chen Chongxi,translation.Beijing:China building industry press, 1983,508—510

[4] Zhao Jing, Yan Zhenpeng, Shao Jingli,Cui Yali,Liu Xinhao,Tian Lianghe,The application of HST3D code in heat mobilization simulation, Resources and industry, 2009, 8

[5] Yang Weitao,Numerical Simulation Pumping-injection Wells Spacing of Ground water Source Heat Pump in Gravel Aquifer,Shenyang Jianzhu university,2012, 12 